\title{
The attitudes and opinions Sosyal bilgiler öğretmen of social studies teacher adaylarının eğitimde candidates on the usage of teknoloji kullanımına ilişkin technology in education tutum ve görüşleri ${ }^{1}$
}

\author{
Ünal Şimşek ${ }^{2}$ \\ Tahsin Yildırım ${ }^{3}$
}

\begin{abstract}
In our country, just like in many other countries in the world, one of the most important goals of national education is to build up citizens who possess the informational and technological equipment necessary to our time, who are in cooperation with the environment they live in, who love their country, motherland and nation, who are adaptable and can produce solutions when faced with problems. When these matters are taken into consideration, Social Studies and the teachers who will teach them have serious duties. This work has been done in order to determine the attitudes and the opinions of social studies teacher candidates about the use of technology in education; the teachers who undertake as a duty the upbringing of well-equipped, qualified and decent citizens.
\end{abstract}

Keywords: The use oftechnology in education, social studies education, technology and attitude in the teaching of social studies, social studies teacher candidates

\section{Özet}

Ülkemizde tüm dünya ülkelerinde olduğu gibi milli eğitimin en önemli amaçlarından birisi; çağın gerektirdiği bilgi ve teknolojik donanımına sahip, içinde yaşadığı çevreyle işbirliği içinde olan, ülkesini, vatanını ve milletini seven, uyumlu, yaşadığı sorunlar karşısında çözüm yolları üretebilen vatandaşlar yetiştirmektir. Bu hususlar göz önünde bulundurulduğunda burada Sosyal Bilgiler dersine ve onu anlatacak olan öğretmenlere önemli görevler düşmektedir. Bu çalışma, donanıml, nitelikli ve iyi vatandaş yetiştirmeyi kendine görev edinen sosyal bilgiler öğretmen adaylarının eğitimde teknoloji kullanımına ilişkin tutumlarının ve görüşlerinin neler olduğu tespit etmek için yapılmıştır.

Anahtar Kelimeler: Eğitimde teknoloji kullanımı, sosyal bilgiler eğitimi, sosyal bilgiler öğretimde teknoloji ve tutum, sosyal bilgiler öğretmen adayları

\section{Extended English abstract is at the end of this} document)

${ }^{1}$ Bu makale, Ünal Şimşek tarafindan hazırlanan "Sosyal Bilgiler Öğretmen Adaylarının Eğitimde Teknoloji Kullanımına İlşikin Tutum ve Görüşlerinin İncelenmesi” adlı yüksek lisans tezinden üretilmiştir.

${ }^{2}$ Arş. Gör., Aksaray Üniversitesi, Eğitim Fakültesi, Sosyal Bilgiler Eğitimi Anabilim Dalı, unalsimsek63@gmail.com

${ }^{3}$ Yrd. Doç. Dr., Aksaray Üniversitesi, Eğitim Fakültesi, Sosyal Bilgiler Eğitimi Anabilim Dalı, tahsinyildirim@msn.com 
Şimşek, Ü. \& Yıldııı, T. (2016). Sosyal bilgiler öğretmen adaylarının eğitimde teknoloji kullanımına ilişkin tutum ve görüssleri. International Journal of Human Sciences, 13(1), 632-649. doi:10.14687/ijhs.v13i1.3506

\section{Giriş}

21. yüzyılda süratle artan bilgi beraberinde teknolojik gelişmeleri de getirmiş ve buna bağlı olarak bilgi üretimi ve dağıtımı da artmıştır. Teknolojinin hızla ilerleyişi karşısında eğitimin durağan kalması söz konusu olamayacağı gibi nitelikli bir eğitim modelinin ortaya çıkması için bilim ve teknolojiyi algılayabilen, üretici bireylerin yetiştirilmesi gerekmektedir. Bunun yanında bilim ve teknolojinin de eğitime entegrasyonu kesinlikle sağlanmalıdır (Çelen, Çelik ve Seferoğlu, 2011). Teknolojik gelişmeleri göz önünde bulundurarak eğitim sistemleri de yeni plan, program ve materyal hazırlamalıdır (Adı̈̈̈zel, 2010; Yeşilyurt, 2007; Karasar, 2004).

Toplumun ihtiyaçlarına yönelik insanlar yetiştirmek eğitimin önemli amaçlarından biri olduğuna göre bilgi çağının gerektirdikleri perspektifte eğitim-öğretime yol çizmek ve eğitim hayatında teknolojiden faydalanmak gerekmektedir (Aydın, 2003). 21.yy' dan itibaren gelişen teknolojinin eğitim sektörüne de hızla girdiği ve bu doğrultuda eğitim alanında yeni yöntem stratejilerin kullanılmasına olanak sağladığ1 görülmüştür. Günümüz bilgi topluluğunun eğitim ihtiyaçları göz önüne alındığında, bilgiye her zaman, her mekânda ve gereksinim duyduğumuz anda ulaşmak ve kullanabilmek önem kazanmıştır. Gelişen teknolojiler eğitime yeni bir boyut kazandırmış ve ihtiyaç duyulan her anda zaman ve mekândan bağımsız bir şekilde eğitim-öğretim programlarına da yansıyarak, yeni yöntem, strateji ve öğrenme alanlarının oluşmasına zemin hazırlamışır. (Çakır, 2011).

Eğitim kurumlarında teknolojiyle birlikte geliştirilen yöntem, strateji ve öğrenme alanlarında verim almak için de eğitim kurumlarının alt yapılarının iyileştirilmesi bununla birlikte öğretmenlerinde teknolojik donanımlarının geliştirilmesi gerekmektedir.

\subsection{Eğitimde Teknoloji Kullanımı}

Ülkelerin gelişmişlik düzeyleri, genellikle, bilim ve teknolojideki başarılarıyla ölçülmektedir. Bu gelişimi sağlamada en temel faktör eğitimdir. Son dönemlerde eğitimde teknoloji kullanımı beraberinde farklı gelissmelere de zemin hazırlamıştır. Gelişen eğitim teknolojisi sayesinde toplumun her kesimindeki insanlar da yaratıcı düşünme ön plana çıkmış ve buna bağlı olarak insanlar sorgulamaya, analiz etmeye, eleştirmeye ve üretmeye başlamışlardır. Bu bilgi becerilerin insan hayatına yansımasında eğitimde teknolojinin kullanılmasının da katkısı yadsinamayacak kadar büyük olmuştur.

İşman’ a (2005) göre; “Ĕğitim Teknolojisinin üç temel özelliği vardır:

\section{Donanimlar}

2. Öğrenme ve öğretme kuramları

3. Öğretim ortamlarının tasarımı”.

Buna göre, İşman (2003) eğitim teknolojisini; Öğretim alanlarını etkili öğrenmeleri oluşturmak için zenginleştirme ve geliştirme süreçlerindeki bütün kuramsal ve pratik çalışmaların bir programlı set halindeki uygulaması olarak ifade etmiştir. Oğuzkan (1993) eğitim teknolojisini, öğretimi etkili hale getirmek için teknik alt yapı ve fiziksel donanımların hazır hale getirilmesi ve problemlere çözümler üretilmesini sağlayan bileşke olarak ifade etmiştir. AECT (1977) eğitim teknolojisini; problemlerin analiz edilmesinde, çözümlenmesinde, yorumlanmasında ve değerlendirilmesindeki tüm boyutları içeren karmaşık kapsamlı süreç olarak tanımlamıştır. Rıza (1997) ise farklı alanların verilerini ölçme ve değerlendirme çerçevesinde ele alıp bunlanı eğitim hayatında pratiğge dönüştüren, niteliğin ve kalitenin artmasını sağlayan bir sistem olarak ifade etmiştir. Gördüğümüz gibi eğitim teknolojisi ile ilgili farklı tanımlanmalar yapılmakla birlikte genel olarak; öğretim alanlarında öğrenmeleri kalıcı, eğlenceli ve nitelikli bir hale getirmek için teknik alt 
Şimşek, Ü. \& Yıldırım, T. (2016). Sosyal bilgiler öğretmen adaylarının eğitimde teknoloji kullanımına ilişkin tutum ve görüşleri. International Journal of Human Sciences, 13(1), 632-649. doi:10.14687/ijhs.v13i1.3506

yap1 ve fiziksel donanım başta olmak üzere mevcut koşulların iyileştirilmesi, sorunlara çözüm yolları üretilerek bunların hepsini bir plan halinde uygulanması olarak tanımlayabiliriz.

\subsection{Sosyal Bilgiler Öğretiminde Teknoloji Kullanımı}

Sosyal Bilgiler dersinin ana amac1, demokratik havayı oluşturarak, nitelikli ve iyi vatandaş yetiştirmektir (Braun, 1999). Nitelikli ve iyi vatandaşın yolu da sorunlara kulak veren bunları çözmede demokratik unsurları göz önünde bulunduran, analize ve eleştirel gözle olaylara bakmayı bilen, sosyal bilgiler programında bulunan hedef ve davranışsal amaçları kendine prensip hale getiren bireylerden geçer (Braun, 1999, Sunal ve Haas, 2005)

Günümüz vatandaşlık becerileri; bilgiye ulaşmayı, bilgiyi belli hedefler doğrultusunda kullanabilmeyi ve bunları inceleyebilmeyi kapsamaktadır.Teknoloji aracıllğıyla bunlara doğrudan ulaşılabilir (Braun, 1999).Teknoloji kullanımı, öğrencileri öğrenmeye odaklarken onların motivasyonunu ve güvenlerini arttırarak kişisel beceri gelişimine katkı sağlar (Heafner, 2004).

$\mathrm{Bu}$ yüzden sosyal bilgiler öğretmenleri öğrenci başarısını ve eğitimde kaliteyi arttırmada öğretim teknolojisinden veya bu teknoloji sonucunda ortaya çıkan ürünlerden yararlanmalıdır (Tarman ve Baytak, 2011).

Heafner (2004) yeni sosyal bilgiler programının bilim ve teknolojiye verdiği önem programın genel amaçlarında da yer aldığını ifade etmiştir.Buna göre sosyal bilgiler dersiyle öğrenciler; bilimsel ve teknolojik gelişmeleri inceler, öğrenir ve gündelik hayatta bu gelişmeleri pratiğe dönüştürerek kavrar.Ayrıca bilimi merkeze alarak ulaşılan bilgiyi, etik değerler içerisinde kullanabilme ahlakını gözetirler (MEB, 2006).

Sosyal bilgiler yeni programında öne çıkan unsurlardan biri öğrenme alanlarıdır. Öğrenme alanı, öğrenmeyi koordine eden birbiriyle ilişkili beceri, tema ve kavramları bütün olarak ele alan yap1 olarak ifade edilebilir (MEB, 2006).

Sosyal bilgiler yeni programında 4.sınıftan 7. sınıfa kadarki süreçte bilim, teknoloji ve toplum ilgili konuların "Bilim, Teknoloji ve Toplum" öğrenme alanı çerçevesinde yapılandırıldığı görülmektedir. Bilim, teknoloji ve toplum öğrenme alanı üniteleri, ders saati süreleri ve toplam ders saatine oranları aşağıdaki tablolarda verilmiştir. Bunlara bakacak olursak;

Tablo 1: Sosyal Bilgiler 4.5.6.7 sınıflarında Bilim, Teknoloji ve Toplum Öğrenme Alanı Üniteleri, Kazanım Sayısı, Ders Saati Süreleri ve Toplam Ders Saatine Oranları

\begin{tabular}{|c|c|c|c|c|c|}
\hline Sinif & Öğrenme Alanı & Ünite & Kazanım Sayıs1 & Süre/Ders Saati* & Oran $1(\%)$ \\
\hline 4.sinif & $\begin{array}{l}\text { Bilim, Teknoloji ve } \\
\text { Toplum }\end{array}$ & İyi Ki Var & 6 & 11 & 12 \\
\hline 5.sinif & $\begin{array}{l}\text { Bilim, Teknoloji ve } \\
\text { Toplum }\end{array}$ & $\begin{array}{l}\text { Gerçekleşen } \\
\text { Düşler }\end{array}$ & 6 & 11 & 12 \\
\hline 6.sinif & $\begin{array}{l}\text { Bilim, Teknoloji ve } \\
\text { Toplum }\end{array}$ & $\begin{array}{l}\text { Elektronik } \\
\text { Yüzyıl }\end{array}$ & 5 & 12 & 10 \\
\hline 7.sinif & $\begin{array}{l}\text { Bilim, Teknoloji ve } \\
\text { Toplum }\end{array}$ & $\begin{array}{l}\text { Zaman İçinde } \\
\text { Bilim }\end{array}$ & 5 & 12 & 10 \\
\hline
\end{tabular}

MEB, 2005a; MEB, 2005b. 
Şimşek, Ü. \& Yıldııı, T. (2016). Sosyal bilgiler öğretmen adaylarının eğitimde teknoloji kullanımına ilişkin tutum ve görüssleri. International Journal of Human Sciences, 13(1), 632-649. doi:10.14687/ijhs.v13i1.3506

Tablo 1'de belirtildiği gibi 4-5-6 ve 7.sınıf sosyal bilgiler dersi sınıf programlarında bilim ve teknolojiyle ilgili konulara yer verilmiştir. Programda yer alan bilimsel ve teknolojik gelişmeler, bu gelişmelerin toplum hayatına etkileri çeşitli etkinlikler, görsel unsurlar, örnek olaylar ve açıklamalar yardımıyla anlatılmaya çalışılmıştır (Yeşiltaş ve Kaymakçı, 2014). Bunun yanında teknoloji ile bütünleştirilmiş sosyal bilgiler öğretiminin etkin bir biçimde uygulanmasında öğretmenlere ve üniversitelere büyük görev düşmektedir. Öğretimde teknolojiyi nitelikli hale getirmek için hem üniversitelerin fiziki koşullarının iyileştirilmesi gerekmektedir hem de teknoloji donanımı olan nitelikli öğretmenlerin yetiştirilmesi gerekmektedir.

\subsection{Problem Durumu}

Bu çalısmanın problemi "Sosyal Bilgiler Öğretmen Adaylarının Eğitimde Teknoloji Kullanımına İlişkin Tutumları ve Görüşleri Nasıldır?” şeklinde belirlenmiştir.Bu ana problem çerçevesinde aşağıda alt problemler ortaya konmuş ve bu problemlere cevap aranmıştır.

\subsubsection{Alt Problemler}

Çalışmanın nicel alt boyutları: Teknolojiye yönelik tutum ölçeği puanları cinsiyet üzerinde, sınıf düzeyleri üzerinde, mezun olunan lise türü üzerinde, öğretim üyelerinin derslerde teknolojik araçgereç kullanma durumu üzerinde, sınıflardaki teknolojik donanımın yeterlik düzeyi üzerinde, derslerde internete bağlanma durumu üzerinde anlamlı bir farklılık gösteriyor mu?

Çalışmanın nitel alt boyutlan: Eğitimde teknoloji kullanımı sizce ne demektir? Ne düşünüyorsunuz?, Teknoloji araç gereç kullanımı ile başanı arasında nasıl bir ilişki olduğunu düşünüyorsunuz?, Mevcut eğitim sürecinizde (üniversitede) hangi teknoloji araç ve gereçlerini kullandınız? Bunların eğitim öğretim hayatınız üzerindeki etkisini nasıl ifade edersiniz?, Bir öğretmen adayı olarak, teknolojik araç gereçleri eğitim hayatında nasıl etkili kullanırsınız?

\section{Yöntem}

Araştırmada nicel ve nitel araştırma yöntemlerinden yararlanılmıştır.Bu bölümde, araştırma deseni, çalışma grubu, veri toplama aracı ve veri analizi yer almaktadır.

\subsection{Araştırma Deseni}

"Sosyal Bilgiler Öğretmen Adaylarının Eğitimde Teknoloji Kullanımına İlişkin Tutum ve Görüşlerinin İncelenmesi” adlı bu çalışma betimsel tarama yönteminde desenlenmiştir. Betimsel taramada çalışmaya dahil olan herşey kendi koşulları içerisinde açıklanmaya çalışıır (Karasar, 2010).Araştırmada veriler, karma yöntem şeklinde yani nitel ve nicel veri toplama araçları birlikte kullanılarak elde edilmiştir (Balc1 2010).Sosyal bilimlerde amaçlı olarak ikiden fazla verinin aynı çalışma içerisinde kullanılmasını karma yöntem yaklaşımı denilmektedir. Nicel yöntem kullanıldığında birçok katılımcıya ulaşma imkanı varken; gözlem, görüşme ve vb. gibi diğer nitel yöntemlerin kullanılmasıyla ise, çalışma daha derinlemesine analiz edilir (Grenee vd., 2005'ten Akt; Beycioğlu ve Aslan, 2012: 198).

\section{2. Çalışma Grubu}

Araştırmanın çalışma grubunu Aksaray Üniversitesi Eğitim Fakültesi Sosyal Bilgiler Öğretmenliği bölümü öğrencileri oluşturmaktadır.Nicel araştırma kısmında Aksaray Üniversitesi Eğitim Fakültesi 
Şimşek, Ü. \& Yıldııı, T. (2016). Sosyal bilgiler öğretmen adaylarının eğitimde teknoloji kullanımına ilişkin tutum ve görüssleri. International Journal of Human Sciences, 13(1), 632-649. doi:10.14687/ijhs.v13i1.3506

Sosyal Bilgiler Öğretmenliği bölümündeki 232 öğrenciye Teknoloji tutum ölçeği uygulanmıştır. Nitel araştırma kısmında ise, 11 öğretmen adayı ile odak grup görüşmesi yapılmıştır. Örneklem belirlenirken amaçlı örnekleme yöntemi kullanılmıştır.Amaçlı örneklemede araştırmacı kimlerle görüşme yapacaksa insiyatif alarak seçimde bulunabilir ve çalışmanın amacina en uygun olan öğrencilerle görüşme yapar (Balc1, 2010).

\subsection{Veri Toplama Arac1}

Bu çalışmada, nicel veriler Yavuz (2005) tarafindan geliştirilen "Teknoloji Tutum Ölçeği" aracillğıyla toplanmıştır.Öğretmen adaylarına Teknoloji Tutum Ölçeği ile birlikte Anket Formu' da verilmiştir.Nitel veriler ise, 11 öğrenciyle yapılan Odak Grup Görüşmesi sonucunda toplanmıştır.Görüşme soruları literatür incelenmiş ve sonrasında uzman görüşü alınarak hazırlanmıştır.Hazırlanmış olunan 6 görüşme sorusu uzman görüşleri sonucunda 4 ' e indirilmiş ve içerik geçerliliği sağlanmıştır.

\subsection{Verilerin Analizi}

$\mathrm{Bu}$ çalışmada elde edile veriler, kullanılan veri toplama tekniklerine uygun olarak analiz edilmiştir.Nicel veriler, SPSS 18.0 (Statistical Package for Social Sciences) programı kullanılarak analiz edilmiştir.Araştırmanın değişkenleri ile Teknoloji Tutum Ölçeği'nden elde edilen toplam puanlar arasındaki ilişkileri belirleyebilmek için farklı analiz teknikleri kullanılmıştır.Çalışmanın nitel verileri odak grup görüşmesi yoluyla toplanmıştır.Görüşmelerden elde edilen veriler içerik analizi tekniğiyle önce ana tema sonra alt temalar altında kodlanmış ve öğretmen adaylarının örnekleri ile desteklenmiştir.

\section{Bulgular}

Bu bölümde ilk olarak, çalışmaya katılan öğrencilerin 'TTÖ' nden elde edilen toplam puanlarryla değişkenler arasındaki ilişkileri ortaya koyan analiz sonuçları yer almaktadır.Daha sonra ise nitel verilerin değerlendirilmesinden elde edilen bulgular yer almaktadır.

\subsection{Teknoloji Tutum Ölçeğinden Elde Edilen Toplam Puanlarla Çalışmanın Değişkenlerine İlişkin Analiz Bulguları}

Analize başlamadan önce, değişkenlere ilişkin eksik verinin olup olmadı̆̆ını belirlemek amacıyla kayıp (missing) değerler incelenmiştir. Değişken setlerinde, eksik veri olmadığ1 tespit edilmiştir.Sonraki aşamada uç değerler incelenmiştir.Uç değer analizinde, veri setinde 10 gözlemin çok değişkenli uç değer gösterdiği görülmektedir ( $\mathrm{p}<0.01)$.Bu nedenle, 10 gözlem veri setinden çıkarılmış, 222 veri ile incelemelere devam edilmiştir.Daha sonra verilerin normallik dağıllımına ilişkin inceleme yapılmıştır.

Grup büyüklüğünün 50'den küçük olduğu durumda Shapiro-Wilks, büyük olduğu durumda ise Kolmogorov-Smirnov (K-S) testi puanların normalliğe uygunluğunun araştırılmasında kullanılan testlerdir (Büyüköztürk, 2012).Örneklem büyüklüğü 50'den büyük olduğu için $(\mathrm{N}=222>50)$ Kolmogorov-Smirnov testi sonucuna bakılmıştır. Çalışmanın Kolmogorov-Smirnov test sonuçları Tablo 2'de gösterilmiştir. 
Şimşek, Ü. \& Yıldırım, T. (2016). Sosyal bilgiler öğretmen adaylarının eğitimde teknoloji kullanımına ilişkin tutum ve görüssleri. International Journal of Human Sciences, 13(1), 632-649. doi:10.14687/ijhs.v13i1.3506

Tablo 2: Kolmogorov-Smirnov Test Sonuçları

\begin{tabular}{|c|c|c|c|c|c|}
\hline \multicolumn{3}{|c|}{ Kolmogorov-Smirnov } & \multicolumn{3}{|c|}{ Shapiro-Wilk } \\
\hline İstatistik & $\mathrm{Sd}$ & $\mathrm{P}$ & İstatistik & $\mathrm{Sd}$ & $\mathrm{P}$ \\
\hline .074 & 222 & .048 & .989 & 222 & .082 \\
\hline
\end{tabular}

Tablo 2 incelendiğinde verilerin, normallik varsayımını sağlamadığı görülmektedir $(\mathrm{p}<0.05)$. Sonuç olarak, yapılan eksik değer, aykırı değer ve normallik analizleri sonucunda veri setinde 222 anket değerlendirmeye alınmış, verilerin analizi için gerekli koşullar sağlanmıştır.

Tablo 3: Teknolojiye Yönelik Tutum Ölçeği Puanlarının Cinsiyete Göre U-Testi Sonuçları

\begin{tabular}{llllll}
\hline Cinsiyet & $\mathrm{N}$ & Sira Ortalamas & Sira Toplamı & $\mathrm{U}$ & $\mathrm{P}$ \\
\hline Kadın & 135 & 115.49 & 15591.00 & 5334.00 & 0.25 \\
Erkek & 87 & 105.31 & 9162.00 & & \\
\hline
\end{tabular}

Tablo 3 incelendiğinde, teknolojiye yönelik tutum ölçeği puanlarının, cinsiyete göre anlamlı bir farklılık göstermediği görülmektedir ( $U=5334.00, \mathrm{p}>.05)$. Sıra ortalamaları dikkate alındığında, kadınların erkeklere göre teknolojiye yönelik tutum puanlarının daha yüksek olduğu anlaşılmaktadır.Bu bulgu, teknolojiye yönelik tutum ile cinsiyet arasında anlamlı bir ilişkinin olmadığ1 şeklinde de yorumlanabilir.

Tablo 4: Teknolojiye Yönelik Tutum Ölçeği Puanlarının Sınıf Düzeyine Göre Kruskal Wallis Testi Sonuçları

\begin{tabular}{lllllll}
\hline Sinıf Düzeyi & $\mathrm{N}$ & Sira Ortalamasi & Sd & $\chi^{2}$ & $\mathrm{P}$ & Anlaml Fark \\
\hline 1.Sınıf & 53 & 114.69 & & & & \\
2.Sınıf & 49 & 113.10 & 3 & 6.55 & .088 & - \\
3.Sinıf & 43 & 89.81 & & & \\
4.Sınıf & 77 & 120.40 & & & \\
\hline
\end{tabular}

Tablo 4 incelendiğinde, öğretmen adaylarının sınıf düzeyleri ile teknolojiye yönelik tutumları arasında anlamlı bir farkll1ık görülmemektedir $\left[\chi_{(\mathrm{sd}=3, \mathrm{n}=222)}^{2}=6.55, \mathrm{p}>.05\right]$. Sira ortalamaları dikkate alındığında, en yüksek tutuma 4. Sinıfların sahip olduğu, bunu sırasıyla 1., 2. ve 3. Sinıfların izlediği görülmektedir. Başka bir anlatımla, ögretmen adaylarının sınıf düzeyleri, onların teknolojiye yönelik tutumlarının anlamlı bir belirleyicisi değildir. 
Şimşek, Ü. \& Yıldırım, T. (2016). Sosyal bilgiler öğretmen adaylarının eğitimde teknoloji kullanımına ilişkin tutum ve görüssleri. International Journal of Human Sciences, 13(1), 632-649. doi:10.14687/ijhs.v13i1.3506

Tablo 5: Teknolojiye Yönelik Tutum Ölçeği Puanlarının Mezun Olunan Lise Türüne Göre Betimsel İstatistik Sonuçları

\begin{tabular}{llllll}
\hline Lisetürü & Mean & $\mathrm{N}$ & Std. Deviation & Minimum & Maximum \\
\hline İmamhatip & 3,9298 & 3 &, 42866 & 3,63 & 4,42 \\
Anadolulisesi & 4,1520 & 162 &, 39255 & 3,11 & 5,00 \\
Fenlisesi & 3,8947 & 1 &. & 3,89 & 3,89 \\
Mesleklisesi & 4,0307 & 12 &, 30890 & 3,58 & 4,63 \\
Cokprogramli & 4,1246 & 30 &, 39325 & 3,21 & 4,84 \\
Anadoluogretmen & 4,1429 & 7 &, 45042 & 3,47 & 4,74 \\
Acikogretim & 4,2632 & 7 &, 46384 & 3,53 & 4,79 \\
Total & 4,1408 & 222 &, 39045 & 3,11 & 5,00 \\
\hline
\end{tabular}

Tablo 5 incelendiğinde, öğretmen adaylarının teknolojiye yönelik tutumlarında ortalama puanları göz önüne alındığında, 4,2632 ortalamayla Açıköğretim liseleri ilk sırada yer alırken, onu sırasıyla 4,1520 ile Anadolu liseleri, 4,1429 ile Anadolu öğretmen liseleri, 4,1246 ile Çok Programlı liseler, 4,0307 ile Meslek liseleri, 3,9298 ile imam hatip liseleri ve 3,8947 ile Fen liseleri takip etmiştir. Öğretmen adaylarının teknolojiye yönelik tutumlarında ortalama puanların yüksek olduğu görülmektedir.

Tablo 6: Teknolojiye Yönelik Tutum Ölçeği Puanlarının Öğretim Üyelerinin Derslerde Teknolojik Araç-Gereç Kullanma Durumuna Göre U-Testi Sonuçları

\begin{tabular}{|c|c|c|c|c|c|c|}
\hline $\begin{array}{l}\text { Teknolojik } \\
\text { Kullanma Durumu }\end{array}$ & Araç-Gereç & $\mathrm{N}$ & Sira Ortalamas1 & Sira Toplamı & $\mathrm{U}$ & $\mathrm{P}$ \\
\hline Kullaniyor & & 168 & 103.71 & 17423.50 & 3227.50 & .001 \\
\hline Kullanmiyor & & 54 & 135.73 & 7329.50 & & \\
\hline
\end{tabular}

Tablo 6 incelendiğinde, teknolojiye yönelik tutum ölçeği puanlarının, öğretim üyelerinin derslerde teknolojik araç-gereç kullanma durumuna göre anlamlı bir farklılık gösterdiği görülmektedir(U= 3227.50, p<.05). Sıra ortalamaları dikkate alındığında, derslerde öğretim üyelerinin teknolojik araçgereç kullanmadığı durumlarda, öğretmen adaylarının teknolojiye yönelik tutum puanlarının daha yüksek olduğu anlaşılmaktadır.Bu bulgu, teknolojiye yönelik tutum ile öğretim üyelerinin teknolojik araç-gereç kullanma durumu arasında anlamlı bir ilişkinin olduğu şeklinde de yorumlanabilir. 
Şimşek, Ü. \& Yıldırım, T. (2016). Sosyal bilgiler öğretmen adaylarının eğitimde teknoloji kullanımına ilişkin tutum ve görüssleri. International Journal of Human Sciences, 13(1), 632-649. doi:10.14687/ijhs.v13i1.3506

Tablo 7: Teknolojiye Yönelik Tutum Ölçeği Puanlarının Sınıflardaki Teknolojik Donanımın Yeterlik Düzeyine Göre Kruskal Wallis Testi Sonuçları

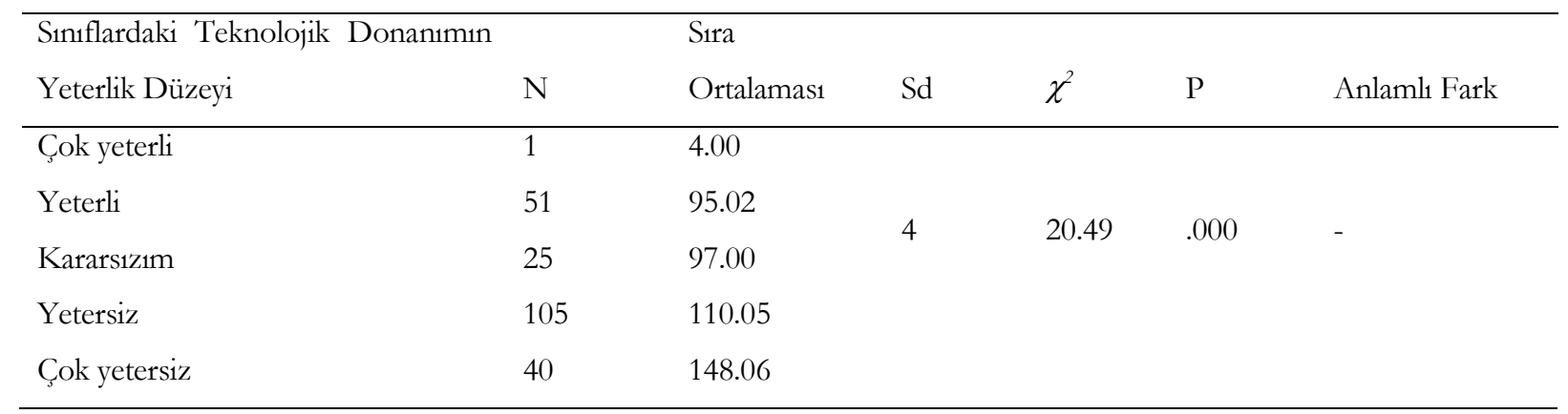

Tablo 7 incelendiğinde sinıflardaki teknolojik donanımın yeterlik düzeyi ile öğretmenlerin teknolojiye yönelik tutumları arasında anlamlı bir farklılık görülmektedir $\left[\chi_{(\mathrm{sd}=4, \mathrm{n}=222)}^{2}=20.49, \mathrm{p}<\right.$ .05].Sıra ortalamaları dikkate alındığında, en yüksek tutuma çok yetersiz teknolojik donanımlı sınıflarda öğrenim gören öğretmen adaylarının sahip olduğu, bunu sırasıyla yetersiz, kararsızım, yeterli ve çok yeterli sınıf donanımlarının izlediği görülmektedir. Başka bir anlatımla, sınıflardaki teknolojik donanımın yeterlik düzeyi, öğretmen adaylarının teknolojiye yönelik tutumlarının anlamlı bir belirleyicisidir.

Tablo 8: Teknolojiye Yönelik Tutum Ölçeği Puanlarının Derslerde İnternete Bağlanma Durumuna Göre U-Testi Sonuçları

\begin{tabular}{llllll}
\hline $\begin{array}{l}\text { Derslerde Internete } \\
\text { Bağlanma Durumu }\end{array}$ & $\mathrm{N}$ & Sira Ortalamas1 & Sira Toplamı & $\mathrm{U}$ & $\mathrm{P}$ \\
\hline Evet & 77 & 90.29 & 6952.00 & 3949.00 & .000 \\
Hayır & 145 & 122.77 & 17801.00 & & \\
\hline
\end{tabular}

Tablo 8 incelendiğinde, teknolojiye yönelik tutum ölçeği puanlarının, derslerde internete bağlanma durumuna göre anlamlı bir farklılık gösterdiği görülmektedir $(\mathrm{U}=3949.00, \mathrm{p}<.05)$. Sira ortalamaları dikkate alındığında, derslerde internete bağlanma imkânının bulunmadı̆̆ı durumlarda, öğretmen adaylarının teknolojiye yönelik tutum puanlarının daha yüksek olduğu anlaşılmaktadır.Bu bulgu, öğretmen adaylarının teknolojiye yönelik tutum ile derslerde internete bağlanabilme imkânı arasında anlamlı bir ilişkinin olduğu şeklinde de yorumlanabilir.

\subsection{Güvenirlik}

$\mathrm{Bu}$ araştırmada, TTÖ’nün güvenirliğini kestirebilmek amacıyla Cronbach Alpha katsayısı kullanılmıştır. “Ölçeğin toplam güvenirlik katsayısı 0.81 olarak bulunmuştur.Psikolojik bir test için hesaplanan güvenirlik katsayısının 0.70 ve daha yüksek olması test puanlarının güvenirliği için yeterli görülmektedir” (Büyüköztürk, 2012: 171).

\subsection{Araştırmanın Nitel Verilerine İlişkin Bulgular}

Öğretmen adaylarının eğitimde teknoloji kullanımına yönelik görüşlerini belirlemek için yapılan bu çalışmada, öğrencilerin teknolojiyi kullanma açısından üniversitenin mevcut durumunu, gerek üniversitede gerekse öğretim üyelerinden beklentilerini dile getirmişlerdir.Çalısmaya katılan 
Şimşek, Ü. \& Yıldırım, T. (2016). Sosyal bilgiler öğretmen adaylarının eğitimde teknoloji kullanımına ilişkin tutum ve görüşleri. International Journal of Human Sciences, 13(1), 632-649. doi:10.14687/ijhs.v13i1.3506

öğrencilerle odak grup görüşmesi yapılmıştır. Odak grup görüşmesi belli bir plan içerisinde yapılan, buna uygun olarak görüşülen kişilerin düşüncelerini ve fikirlerini toplumsal bir çerçevede ele alan nitel veri tekniğidir (Çokluk, Yılmaz ve Oğuz, 2011). Çalışmaya katılan öğrenciler 4 soruya cevap vermişlerdir. Sorular;

- Eğitimde teknoloji kullanımı sizce ne demektir? Ne düşünüyorsunuz?

- Teknoloji araç gereç kullanımı ile başarı arasında nasıl bir ilişki olduğunu düşünüyorsunuz?

- Mevcut eğitim sürecinizde (üniversitede) hangi teknoloji araç ve gereçlerini kullandınız? Bunların eğitim öğretim hayatınız üzerindeki etkisini nasıl ifade edersiniz?

- Bir öğretmen adayı olarak, teknolojik araç gereçleri eğitim hayatında nasıl etkili kullanırsınız? şeklinde olmuştur.

Öncelikle her soru kendi içerisinde incelenmiş ve analiz sonucunda uzmanlarla beraber önce alt temalar sonra ana tema belirlenmiş, bunlara ek olarak frekans (f) ve yüzde (\%) oranları tespit edilmiş ve tablolara eklenmiştir.

Tablo 9: 1.soru: Eğitimde teknoloji kullanımı sizce ne demektir? Ne düșünüyorsunuz?

\begin{tabular}{|c|c|c|c|}
\hline Ana Tema & Alt Temalar & Frekans $(\mathrm{f})$ & Yüzde \% \\
\hline \multirow{5}{*}{ Nitelikli Öğrenme Alanı } & Kaliteyi Artırarak & & \\
\hline & Zamandan tasarrufu sağlamak & 5 & 45,5 \\
\hline & $\begin{array}{l}\text { Anlaşılır, Kalıcı, Faydalı, Eğlenceli bir } \\
\text { öğrenim sürecinin yaşanmasını } \\
\text { sağlamak }\end{array}$ & 4 & 36,4 \\
\hline & & 2 & 18,1 \\
\hline & $\begin{array}{l}\text { Öğgretim yöntemlerinin çeşitlenmesini } \\
\text { sağlamak }\end{array}$ & & \\
\hline
\end{tabular}

Tablo 9' da görüldüğü gibi 1.soruya "Eğitimde teknoloji kullanımı sizce ne demektir? $\mathrm{Ne}$ düşünüyorsunuz?" verilen cevapların uzmanlarla birlikte analizi ve araştırmacının görüşme esnasındaki gözlemlerinden hareketle ana tema "Nitelikli Öğrenme Alanı ", en çok frekansa ve yüzdeye sahip olan alt tema ise \%45,5 "Kaliteyi Artırarak zamandan tasarrufu sağlamak diyenler" olurken, en çok ikinci frekansa ve yüzdeye sahip olan alt tema \%36,4 ile "Öğretimin Anlaşılır, Kalıc1, Faydalı ve Eğlenceli bir hal alması diyenler", en çok üçüncü frekansa ve yüzdeye sahip olan alt tema ise \%18,1 ile "Yeni Yöntemlere olanak vermek diyenler" olmuştur. Bunlarla ilgili öğretmen adaylarının görüssleri;

" Daba kaliteli, nitelikli bir eğitim için teknolojiden yararlanmaktur. Ayrnca daba az. zabmetli olduğu içinde faydalddr. Yani tabtaya yaz yazmak yerine yazılar, resimler tabtaya yansitnlarak zaman daba tasarruflu kullanmıss oluru₹:Că̆a ayak uydurabilmek için yeniliğe açı olmak gerekir. Günümür dünyasinda teknoloji ve

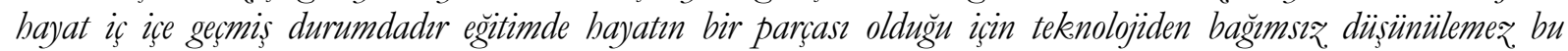
nedenle teknolojiyi hayatımı̨dan çıkaramayacağımıza göre onu faydah olacak, şekilde kullanmalyzı:" (S4)

"Eğitimde teknoloji kullanum denilince aklima ilk gelen; eğitim ortammda var olan bilgilerin daha anlaşllir ve daha kaha olabilmesi için teknolojik gelismelerin eğitim hayatına belirli fayda ve amas doğrultusunda aktarılması 
Şimşek, Ü. \& Yıldırım, T. (2016). Sosyal bilgiler öğretmen adaylarının eğitimde teknoloji kullanımına ilişkin tutum ve görüssleri. International Journal of Human Sciences, 13(1), 632-649. doi:10.14687/ijhs.v13i1.3506

gelmektedir. Teknolojinin her türlü sahada kullanulmasindan nasibini eğitim de almusttr.Böylece her türlü teknolojik. araç ve gereçlerin önemi artmıs, ögretim yöntemlerinin işlenişi daba da kolaylaşmıştır." (H4)

"Teknolojinin gelismesi demek, her alanda olduğu gibi eğitimde de etkili ögretmeyi daba iyi uygulayabilmek için yeni yöntemlerin ortaya çıkması demektir.Örneğin bilgisayarlarn daha çok gelismesiyle beraber sine içinde anlatılan bir konunun bilgisayar destekli ögretim ile daha iyi anlasslabilmesi ve örnek gösterme imkânmmn daha çok olmast bunlardan bir tanesidir." (A4)

Tablo 10: 2.soru: Teknoloji araç gereç kullanımı ile başarı arasında nasıl bir ilişki olduğunu düşünüyorsunuz?

\begin{tabular}{llll}
\hline Ana Tema & Alt Temalar & Frekans (f) & Yüzde \% \\
\hline
\end{tabular}

Olumlu

Bilinçli Olma

Tablo 10' da görüldüğü gibi 2.soruya " Teknoloji araç gereç kullanımı ile başarı arasında nasıl bir ilişki olduğunu düşünüyorsunuz?" verilen cevapların uzmanlarla birlikte analizi ve araştırmacının görüşme esnasındaki gözlemlerinden hareketle ana tema "Bilinçli olma " , en çok frekansa ve yüzdeye sahip olan birinci alt tema ise $\% 81,8$ ile " olumlu " olurken, en çok frekansa ve yüzdeye sahip olan ikinci alt tema ise \%18,2 ile " Hem olumlu hem olumsuz " olmuştur. Bununla ilgili ögretmen adaylarının görüşleri;

"Ögrretimde kullanlan teknolojik aras ve gereçler ögrencinin birden faحla duyu organna bitap ettiü için ögretimi kolaylasstırr buda ögrencilerin bașarnsinda olumlu bir etkendir. Ögrenci bilgivi olabileceğinden daha hræl ve daha kolay ögreniyor. Teknolojik araçlar kullanularak derste konuyla ilgili eğitsel oyunlarla ve yapulan alsstırmalarla bilgi daha kalic hale getiriliyor ve ögrenciye konularn tekrarnda kolaylhk sağhlyor. Yani eğitimde kullanulan teknolojik aletler ögrencinin derse karş güdülenme ve hąır bulunusluk durumunu arttrarak bașarssma olumlu bir etki sağhlyor." (S3)

"Bu iliskei olumlu veya olumsuz olabilmektedir.Derslerde islenen konular artık sanal ortamlarda da cokeça bulunmakta, bunun yaninda konular ile bağlantıl etkinlikler sıklikla karsımıza çımaktadır.Kişinin kendi faydasma göre teknoloji kullanmı ashnda onun basarısm etkileyen yollardan bir tanesidir.Eğer kendi faydasina göre kullanmaynp basska alanlarda vakit kaybina uğrarsa (teknolojik araçlarda) bu onun ders notlarmm düsmesine sebep olabilir." (A4)

Tablo 11: 3. soru: Mevcut eğitim sürecinizde (üniversitede) hangi teknoloji araç ve gereçlerini kullandınız? Bunların eğitim öğretim hayatınız üzerindeki etkisini nasıl ifade edersiniz?

\begin{tabular}{llll}
\hline Ana Tema & Alt Temalar & Frekans (f) & Yüzde \% \\
\hline Hareketli ve görsel öğeler & $\begin{array}{l}\text { Bilgisayar, projeksiyon cihazı, akıllı } \\
\text { tahtalar }\end{array}$ & 11 & 100
\end{tabular}


Şimşek, Ü. \& Yıldırım, T. (2016). Sosyal bilgiler öğretmen adaylarının eğitimde teknoloji kullanımına ilișkin tutum ve görüssleri. International Journal of Human Sciences, 13(1), 632-649. doi:10.14687/ijhs.v13i1.3506

Tablo 11' de görüldüğü gibi 3.soruya " Mevcut eğitim sürecinizde (üniversitede) hangi teknoloji araç ve gereçlerini kullandınız? Bunların eğitim öğretim hayatınız üzerindeki etkisini nasıl ifade edersiniz?" verilen cevapların uzmanlarla birlikte analizi ve araştırmacının görüşme esnasındaki gözlemlerinden hareketle ana tema "Hareketli ve görsel öğeler ", en çok frekansa ve yüzdeye sahip olan alt tema ise \%100 ile " Bilgisayar, Projeksiyon Cihazı, Akıllı Tahtalar" olmuştur. Bununla ilgili ögrretmen adaylarının görüşleri;

"Üniversitedeki araç ve gereç imkân gerçekten çok çessitlidir ve bunlar öğrencinin dersi daha iyi anlamasina yönelik faaliyetlerdir.2011 ynlindan itibaren basladiğm üniversite bayatımda projeksiyon, bilgisayar vs. arac geregleri konularmm itibariyle sılklkela kullandim.Bunun bana en iyi faydası klasik anlatım tarzından kurtulup daba farkh yöntemleri anlamam ve uygulamam oldu.Ödevlerimizi anlaturken teknolojik aras ve gereglerden siklikla faydalanıp kendimizi daha iyi ifade etme imkân bulduk." (A4)

"Eğitim sürecimizde derslerimize yardimc olmast amacylla bilgisayar, akull tabta ve projeksiyonu kullandik. Kullanulan eğitim teknolojileri ile kısa sürede daha hızl ve daha geniş kitleye bilgi aktarmm sağlandı, hareketli ve görsel ögeler motivasyon artırmaya yardımo oldu, görerek ögrenme sayesinde bilgilerin daha etkili ve kaho olması sağland..Ë̆itim fakëiltelerinde kullamlan eğitim teknolojileri ögrretmen adaylarna meslek bayatlarnnda bu teknolojileri en etkili nasıl kullanabileceğine dair fikir vermektedir.Bu yü̊den eğitim fakülttelerinde öğretmen adaylarna teknolojik araç-gereçlerin derslerde uygulanmast için gerekli bilgi ve becerilerin kazandirlması amacyla derslere ağrrlk verilmelidir. Aynca ögretmenlere teknolojik gelismeler ve arac-gereglerin etkin kullanım bususunda biæmet içi eğitim verilmelidir." (H3)

Tablo 12: 4.Bir öğretmen adayı olarak, teknolojik araç gereçleri eğitim hayatında nasıl etkili kullanirsiniz?

\begin{tabular}{lllll}
\hline Ana Tema & Alt Temalar & Frekans (f) & Yüzde \% \\
\hline & $\begin{array}{l}\text { Farklı yöntemlerle anlatımı } \\
\text { kılma }\end{array}$ & etkin & 8 & 82 \\
\cline { 2 - 4 } Yaşantıya Dönüştürme & Yaş, gelişime uygun anlatım & 1 & 9 \\
\cline { 2 - 4 } & Kararsız & 1 & 9 \\
\hline
\end{tabular}

Tablo 12' de görüldüğü gibi 4.soruya " Bir öğretmen adayı olarak, teknolojik araç gereçleri eğitim hayatında nasıl etkili kullanırsınız?" verilen cevapların uzmanlarla birlikte analizi ve araştırmacının görüşme esnasındaki gözlemlerinden hareketle ana tema "Yaşantıya Dönüştürme", en çok frekansa ve yüzdeye sahip olan alt tema \%82 ile " Farklı yöntemlerle anlatımı etkin kılma" olurken, en çok frekansa ve yüzdeye sahip olan ikinci alt tema \%9 ile "Yaş, gelişime uygun", en çok frekansa ve yüzdeye sahip olan üçüncü alt tema ise \% 9 ile "Kararsı" olmuştur. Bununla ilgili öğretmen adaylarının görüşleri;

"Çağa uygun bireyler yetiștirmek isteyen ögretmenler bilim ve teknolojinin hrøla gelistigü günümü̃de geleneksel ögretim yöntemleri yerine özgür, yaraticn, çö̊üm üretebilen, özgüveni yülksek bireyler yetistivebilmek amacylla eğitim teknolojisinden yararlanmahdir. Mesela; Kültür Bakanluğg’nn bir hiə̌meti olan sanal müze uygulamasiyla maddi olanaklar yetersiz olan, fizilksel engelleri nedeniyle gidip göremeyen ögrencilerimize farklı şebirlerdeki önemli taribi

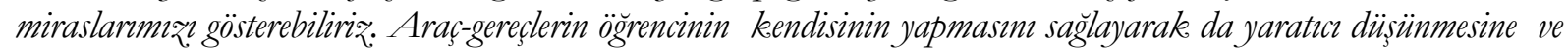
ögrendiklerinin daha kahic olmasina bu sekilde yardımo olabiliri:" (H3) 
Şimşek, Ü. \& Yıldııı, T. (2016). Sosyal bilgiler öğretmen adaylarının eğitimde teknoloji kullanımına ilişkin tutum ve görüssleri. International Journal of Human Sciences, 13(1), 632-649. doi:10.14687/ijhs.v13i1.3506

"Ben bir ögrretmen olarak ögrencilerimin yaş ve gelişimine göre olumlu anlamda katker yapacă̆gna inandĭğm araçlar önce iyi şekilde belirler ondan sonra da görselliği ön plana çıaracak verileri kullanarak sanki olaylar bire bir yasıyormus havası vererek. bu șekilde daba kolay anlamalarm sağlardım." (Y2)

"Son dönemlerde eğitim alannda uygulanan fatih projesi kapsammdaki yeniliklere ayak uydurabilecek düreyde değilim. Örneğin; öğrencilere verilen tabletlerin nasıl kitap olarak kullanuldiğm, sinflara konulan akıll tabtanm nasıl kullamldiğgn bilmiyorum ve buna yöne yönelike herbangi eğitim almadim öte yandan bilhassa tassra da bambaska bir durum söz. konusu yani oradaki smeflarda bala tabta ve tebesir kullamlmakta yani iki nokta bulunmakta biz, bu iki us noktanm tam ortasinda bulunmaktayn yani fatih projesi uygulanan okullara göre yetersiz. bir eğitimci yada ögretmenken taşrada ise daba etkili bir eğitimci yada ögretmeniz:" (S4)

\section{SONUÇ VE TARTIŞMA}

\subsection{Nicel Yöntem kısmında TTÖ' n deki değişkenlere bakacak olursak;}

1.TTÖ puanlarının, cinsiyet üzerinde anlamlı farklılı̆̆a yol açmamaktadır. Bu bulgu, teknolojiye yönelik tutum ile cinsiyet arasında anlamlı bir ilişkinin olmadığ1 şeklinde de yorumlanabilir.Ancak sıra ortalamaları dikkate alındığında, kadınların erkeklere göre teknolojiye yönelik tutum puanlarının daha yüksek olduğu anlaşılmaktadır.

2. TTÖ puanlarının, sınıf düzeyleri üzerinde anlamlı farklılığa yol açmamaktadır.Başka bir anlatımla, öğretmen adaylarının sınıf düzeyleri, onların teknolojiye yönelik tutumlarının anlamlı bir belirleyicisi değildir.En yüksek tutuma 4. Sınıfların sahip olduğu, bunu sırasıyla 1., 2. ve 3. Sınıfların izlediği görülmektedir.

3. TTÖ puanlarının, mezun olunan lise türü düzeyleri üzerinde anlamlı farklılı̆ga yol açmamaktadır. Başka bir anlatımla öğretmen adaylarının mezun oldukları lise türü, onların teknolojiye yönelik tutumlarının anlamlı bir belirleyicisi değildir.

4. TTÖ puanlarının, öğretim üyelerinin derslerde teknolojik araç-gereç kullanma durumuna göre anlamlı bir farklılık gösterdiği görülmektedir.Bu bulgu, teknolojiye yönelik tutum ile öğretim üyelerinin teknolojik araç-gereç kullanma durumu arasında anlamlı bir ilişkinin olduğu şeklinde de yorumlanabilir.Ancak sıra ortalamaları dikkate alındığında, derslerde öğretim üyelerinin teknolojik araç-gereç kullanmadığ durumlarda, öğretmen adaylarının teknolojiye yönelik tutum puanlarının daha yüksek olduğu anlaşılmaktadır.Buradaki anormalliğin nedeni öğretmen adaylanı, öğretim üyelerinin teknolojik araç-gereç kullanımında sürekli projeksiyon cihazını kullandığını ifade etmişlerdir.Farklı teknolojik araç-gereçlerin tercih edilmemesi öğretmen adaylarının derslerde sıkılmasına neden olduğu ifade edilmiştir.Bununla birlikte bu tutum ters yöne doğru yüksek tutum göstermiştir yani ders de teknolojik araç-gereç kullanılmadığı zaman öğretmen adayları daha yüksek tutum göstermişlerdir.Öğretmenlerin teknolojik açıdan kişisel donanımlarının yetersiz oluşundan, eğitim kurumlarının fiziki ve teknik yetersiz oluşuna temas eden çalışmaların bulgularıyla araştırmamızın bulguları örtüşmektedir. Bunlara bakacak olursak; Saffron (2008), Derfler (2002) okulların teknolojik donanım açısından yetersizliği ve öğrencilerin teknoloji becerilerinin eksikliği tutum ve öğrenme üzerinde engelleyici unsurlar olmuşlardır.Aynı zamanda teknoloji ile birleştirilmiş olan öğretim konusunda öğretmenlerin donanımın iyileştirilmemesi, bunun yanında okulun ve sınıfların fiziki yapısında kaynaklanan eksikler (sınıfin büyüklügü̈-küçüklüğü, bilgisayar ve diğer teknolojik araç-gereç eksikleri) teknolojiyle öğretimi birleştirme konusunu engellemektedir.Erduran ve Tataroğlu'nun (2009) gerçekleştirdikleri çalışmalarında sınıflarda yeni teknolojilerin kullanılmasında öğretmenlerin bu araç-gereçlerden (etkileşimli tahtayı) kullanmada becerilerinin eksik olduğuna vurgu yapmıştır.

5. TTÖ puanlarının, sınıflarda teknolojik donanımın yeterlik düzeyi ile öğretmen adaylarının teknolojiye yönelik tutumları arasında anlamlı bir farklılık görülmektedir. Başka bir anlatımla, sınıflardaki teknolojik donanımın yeterlik düzeyi, öğretmen adaylarının teknolojiye yönelik 
Şimşek, Ü. \& Yıldırım, T. (2016). Sosyal bilgiler öğretmen adaylarının eğitimde teknoloji kullanımına ilișkin tutum ve görüssleri. International Journal of Human Sciences, 13(1), 632-649. doi:10.14687/ijhs.v13i1.3506

tutumlarının anlamlı bir belirleyicisidir.Sıra ortalamaları dikkate alındığında, en yüksek tutuma çok yetersiz teknolojik donanımlı sinıflarda öğrenim gören öğretmen adaylarının sahip olduğu, bunu sırasıyla yetersiz, kararsızım, yeterli ve çok yeterli sınıf donanımlarının izlediği görülmektedir.Sınıflardaki teknolojik donanımın yeterlik düzeyi öğretmen adaylarının teknolojiye yönelik tutumları üzerinde anlamlı bir etkiye sahip olduğu görülmektedir. Ancak sıra ortalamaları dikkate alındığında en yüksek tutuma çok yetersiz teknolojik donanımlı sınıfların sahip olduğu, en az tutuma da çok yeterli sınıfların sahip olduğu görülmektedir. Buradaki anormal sonuçta yukarıdaki öğretim üyelerinin derslerde teknolojik araç-gereç kullanma durumundaki değişken ile aynı doğrultudadır yani donanım eksikliğinden, teknolojik araç-gereçlerin yanlış ve bilinçsiz kullanımından, bunlar bağlı olarak da dersin sıkıcı bir hal almasından kaynaklanan nedenlerdir.Bu iki değişkenimizde de aynı bulgulara ulaşarak tutarlı bir sonuç elde etmiş bulunmaktayız.Şahin (2000) ve Schroll (2007) yaptıkları çalısmalarında öğreticilerin donanım eksikliğine vurgu yaparken bunun yanında teknik ve fiziki eksikliğe de dikkat çekmişlerdir.Bu çalışmalarla da araştırmamız benzer bulgulara ulaşmıştır.

6. TTÖ puanlarının, derslerde internete bağlanma durumuna göre anlamlı bir farklılık gösterdiği görülmektedir. Bu bulgu, öğretmen adaylarının teknolojiye yönelik tutum ile derslerde internete bağlanabilme imkanı arasında anlamlı bir ilişkinin olduğu şeklinde de yorumlanabilir.Sıra ortalamaları dikkate alındığında, derslerde internete bağlanma imkânının bulunmadığı durumlarda, öğretmen adaylarının teknolojiye yönelik tutum puanlarının daha yüksek olduğu anlaşılmaktadır.Buradaki anormalliğin nedeni de yukarda belirttiğim bulgularla aynı doğrultudadır.Öğretmen adaylarıyla yapılan görüşmelerde bu bulguların nedeni sorulduğunda; Sınıflarda internetin sinırlı olmasıyla birlikte öğretim üyelerinin bilinçsiz kullanması gösterilmiştir.Burada ve diğer değişkenlerimizde de gördüğümüz gibi öğreticilerin donanımsız olması ve fiziki alt yapının yetersiz olması tutumu son derece etkilemektedir.Akkoyunlu (2002) öğretmenlerin internet kullanımı üzerinde yapmış olduğu çalışmasında internetin öğretim üzerinde etkisiz kalma nedenlerine vurgu yapmıştır.Bunlara bakacak olursak; Eğitim kurumların alt yapısının zayıf olması, teknolojiye kurumlarda ve evlerde erişimin kısıtlı olması, öğretmenlerin teknolojiyi kullanma açısından yetersiz olması, teknoloji ve internetin öğretimde birlikte kullanılmaması olarak sıralamıştır.

\subsection{Nitel yöntemlerden olan odak grup görüşmesi sonucunda yapılan içerik analizlerde şu bulgular elde edilmiştir;}

1. Eğitimde teknoloji kullanımı sizce ne demektir? Ne düşünüyorsunuz?adlı soruya verilen cevaplara baktığımızda öğretmen adayları teknolojiyi genel olarak nitelikli öğrenme alanı olarak ifade etmişlerdir. Ögrretmen adaylarının bu ana temayı destekleyen alt temalarına bakacak olursak; a)Kaliteyi Artırarak Zamandan tasarrufu sağlama, b) Anlaşılır, Kalıcı, Faydalı, Eğlence, c) Yeni yöntemler gelmektedir. Buradan da hareketle teknolojinin öğretimde önemli bir unsur olduğu, bununla birlikte teknolojinin öğretimde yeni yöntemlere kapı açarak öğretimi daha anlaşılır, kalıcı, faydalı ve eğlenceli bir hale getirdiği sonucuna da varmış bulunmaktayız. Darren (2004), Gündüz (2009) ve Karademir (2009) tarafindan yapılmış olan çalışmaları da çalışma grubumuzdaki öğretmen adaylarıyla yapılan görüşmeler sonucunda elde ettiğimiz bulgularla örtüşmektedir.Çalışmalarında teknolojiden yararlanmanın öğrenci başarılarını artırdığı, derse yönelik tutumlarını pozitif yönde etkilediği, öğretim teknolojilerinin öğrenci başarısına ve öğrenmesine yönelik tutumlanna etkide bulunduğu tespitine varmıslardır.

2. Teknolojik araç-gereç kullanımı ile başarı arasında nasıl bir ilişki olduğunu düşünüyorsunuz? adlı soruya verilen cevaplara baktığımızda öğretmen adayları, teknolojik araç-gereç kullanımı ile başarı arasındaki ilişkiyi; bilinçli olarak kullanıldığında olumlu etkilerinin olacağı şeklinde ifade ederlerken, bilinçsiz kullanıldığında ise olumsuz etkilere neden olabileceğini söylemişlerdir. TTOÖ'nde elde etmiş 
Şimşek, Ü. \& Yıldırım, T. (2016). Sosyal bilgiler öğretmen adaylarının eğitimde teknoloji kullanımına ilișkin tutum ve görüssleri. International Journal of Human Sciences, 13(1), 632-649. doi:10.14687/ijhs.v13i1.3506

olduğumuz bulgularda da teknolojinin öğretimde kullanımına tutum yüksek çıkarken öğretim üyelerinin teknolojik araç-gereç kullanımından ön bilgilerinin olmaması, eğitim kurumlarının gerek fiziki yetersizliğinden gerekse de alt yapı eksikliğinden dolayı bu tutumlar olumsuz yöne kayma göstermiştir.Bu bulgumuzla örtüşen çalışmalara yukarda TTÖ' n deki bulguların analiz kısmında yer verilmiştir.

3. Mevcut eğitim sürecinizde (üniversitede) hangi teknoloji araç ve gereçlerini kullandınız? Bunların eğitim öğretim hayatınız üzerindeki etkisini nasıl ifade edersiniz?adlı soruya verilen cevaplara baktığımızda öğretmen adayları, bilgisayar, projeksiyon cihazı, akıllı tahtalar kullandıklarını ifade etmişlerdir. Bu araçları öğretmen adayları öğrenme ortamında kullandıkları zaman görsel hafızalarında daha kalıcı olduklarını ifade etmişlerdir.Bulgularımızı destekleyen çalışmalara baktığımızda Tutgun ve Özdener (2011) ' de yaptıkları araştırmalarının bulgularına göre, bilgisayar tabanlı öykü tamamlama çalışmasının, metin tabanlı öykü tamamlama çalışmasına göre daha olumlu sonuçlar doğurduğunu tespit etmiştir.Buradan hareketle de bilgisayar ve diğer teknolojik araçgereçlerin öğrencilerin dikkati ve ilgisi üzerinde daha pozitif etkilere sahip olduğunu ifade etmişlerdir.Özdener ve Oztok' da (2008), yaptıkları araştırmalarında bu sonuçları destekleyen araştırma bulguları ulaşmışlardır. İnternet tabanlı işbirlikli projelerde yani bilgisayar ortamında yer alan öğrencilerin, uygulamaya katılmayan öğrencilere kıyasla bilgi ve iletişim teknolojilerini kullanabilme becerisinde ve öğrenmelerinde daha başarılı olduklarını belirlemişlerdir.

4. Bir öğretmen adayı olarak, teknolojik araç gereçleri eğitim hayatında nasıl etkili kullanırsınız? adlı soruya verilen cevaplara baktığımızda öğretmen adayları, teknolojik araç-gereçleri etkin kullanmayı yaşantıya dönüştürme olarak ifade etmişlerdir. Bunu gerçekleştirmenin yolu da anlatımı farklı yöntemlerle etkin kılmaktan ve yaş, gelişime uygun anlatımı göz önünde bulundurmaktan geçtiğini ifade etmişlerdir.Çalışmamızda elde ettiğimiz bulgularla Adıgüzel, Gürbulak ve Sarıçayır (2011) tarafından yapılan çalışmanın bulguları örtüşmektedir.Çalışmalarında teknolojik araç gereçlerle kapsamlı ve sürekli eğitim alınmasına vurgu yapmışlardır.Bu eğitimler sonucunda örneğin akıllı tahta daha etkili kullanılarak öğrenmede kalıcılık sağlanır şeklinde bulgulara ulaşmışlardır.

\section{5. ÖNERİLER}

Çalışmamızda elde etmiş olduğumuz bulgulara göre eğitimde teknoloji kullanımında bazı eksikler ve yanlışlar göze çarpmaktadır. Bunların giderilmesine yönelik önerilere bakacak olursak;

1. Eğitimde teknoloji kullanma sürecinde yapılacak uygulamalara hem öğretmen adayları hem de öğretim üyeleri dahil edilmeli böylece tüm ilgililer arasında koordineli bir çalışma oluşacaktır.

2. Eğitimde teknolojiyi etkili kullanmayı gerçekleştirmek için öğretmen yetiştiren bu kurumların donanım açısından eksikliklerinin giderilmesi ve mevcut durumunun geliştirilmesi gerekir.

3. Sosyal bilgiler öğretim programında teknoloji ile bütünleştirilmiş sosyal bilgiler öğretimine ilişkin materyaller geliştirilmelidir.

4. Sosyal Bilgiler Öğretmenliği Programlarında verilmekte olan Bilim, Teknoloji ve Sosyal Değişim, Bilgisayar I, Bilgisayar II, Öğretim Teknolojileri ve Materyal Tasarımı gibi derslerin içeriklerine teknolojinin eğitimde kullanabilirliği üzerine konular eklenmelidir.

5. Eğitimde teknoloji kullanan bütün öğreticilere hizmet içi eğitimi alma olanakları artırılmalıdır.

6. Araştırma yapıldığı çalışma grubu ile sinırlı olduğundan farklı bölümlerde öğrenim gören öğretmen adaylarıyla da yapılarak, araştırma konusuna ilişkin farklı sonuçlar toplanabilir. 
Şimşek, Ü. \& Yıldııı, T. (2016). Sosyal bilgiler öğretmen adaylarının eğitimde teknoloji kullanımına ilişkin tutum ve görüşleri. International Journal of Human Sciences, 13(1), 632-649. doi:10.14687/ijhs.v13i1.3506

\section{KAYNAKLAR}

Adıgüzel, A. (2010). İlköğretim okullarında öğretim teknolojilerinin durumu ve sinıf öğretmenlerinin bu teknolojileri kullanma düzeyleri.Dicle Üniversitesi Ziya Gökalp Eğitim Fakë̈ltesi Dergisi, 15, 1-17.

Adıgüzel, T., Gürbulak, N. \& Sarıçayır, S. (2011). Akıllı tahtalar ve öğretim uygulamaları.Mustafa Kemal Üniversitesi Sosyal Bilimler Enstitüsü Dergisi, 8(15), 457-471.

AectTask Force (1977). Educational Technology: Definiton and Glossary of Terms. Washington, D.C:Association for Educational Communications andTechnology.

Akkoyunlu, B. (2002).Öğretmenlerin internet kullanımı ve bu konudaki öğretmen görüşleri, Hacettepe Üniversitesi Eğitim Fakültesi Dergisi, 22, 1-8.

Aydın, B. (2003). Bilgi toplumu oluşumunda bireylerin yetiştirilmesi ve matematik öğretimi.Pamukkale Üniversitesi Eğitim Fakülttesi Dergisi, 2(14), 183-190.

Balc1, A. (2010). Sosyal Bilimlerde Araştırma Yöntem, Teknik ve İlkeler, Pegem Yayıncllk, (8.Baskı), Ankara.

Beycioğlu, K.,\& Aslan, B. (2012), Öğretmen ve Yöneticilerin Öğretmen Liderliğine İlişkin Görüssleri: Bir Karma Yöntem Çalışması, Kuram ve Uygulamada Eğitim Yönetimi, Cilt 18, Sayı 2, ss: 199-223

Braun Joseph, A. (1999). Ten Ways to İntegrate Technology into Middle School Social Studies.The Clearing House, 72(6), 345-351.

Büyüköztürk, Ş. (2012), Sosyal Bilimler İçin Veri Analizi El Kitabı. Ankara: Pegem Akademi Yaymollk.

Çakır, H. (2011). Mobil öğrenmeye ilişkin bir yazılım geliştirme ve değerlendirme.Cukurova Üniversitesi Ë̆itim Fakültesi Dergisi, 2(40), 1-9.

Çelen, F. K., Çelik, A., \&Seferoğlu, S. S. (2011). Türk Eğitim Sistemi ve PISA Sonuçları.Akademik Bilişim 2011, (2-4 Şubat), İnönü Üniversitesi, Malatya.

Çokluk, Ö., Yılmaz, K.,\& Oğuz, E. (2011). Nitel Bir Görüşme Yöntemi: Odak Grup Görüşmesi, Kuramsal Eğitimbilim dergisi, 4 (1), 95-107

Darren, R. (2004). Educational Technology'sImpact on Student Attitudes in High School Social Studies.Royal Roads University.

Derfler, K. E. (2002). Factors which affect middle school teachers' willingness to utilize technology as an instructional tool. Doktora Tezi. La Sierra University, California.

Erduran, A. \& Tataroglu, B. (2009). ComparisonOf The Science And Mathematics Teachers' Opinions On The Usage Of Interactive Whiteboard In Education. 9th International EducationalTechnology Conference (IETC2009). Ankara

Gündüz, M. (2009).Internet teknolojilerini kullanarak ögrenci başarısı ve ögrenmenin kahcoliğm artırma. Yüksek Lisans Tezi, Bahçeşehir Üniversitesi, İstanbul.

Heafner, T.(2004). Using Technology to Motivate Students to Learn Social Studies.Contemporary Issues in Technology and Teacher Education, 4(1), 42-53.

İşman, A., (2005). Öğretim Teknolojileri ve Materyal Geliştirme. Ankara: Pegem Akademi Yaymnclık

İşman, A.,(2003). Bilişim Teknolojileri Işı̆̆ında Eğitim (BTEI), Uluslararası Online Eğitim Teknolojileri Dergisi, Ankara: Ortadoğu Teknik Üniversitesi.

Karademir, E. (2009). Bilgisayar destekli ögretimin ögrencilerin fen ve teknoloji dersi elektirik ünitesindeki akademik başarn düzeylerine, bilimsel süreç becerilerine ve tutumlarn etkisi. Yüksek Lisans Tezi, Eskişehir Osmangazi Üniversitesi, Eskişehir.

Karasar, N. (2010). Bilimsel Araştırma Yöntemi, (21.Baskı), Ankara: Nobel Yayıncllk.. 
Şimşek, Ü. \& Yıldııı, T. (2016). Sosyal bilgiler öğretmen adaylarının eğitimde teknoloji kullanımına ilişkin tutum ve görüşleri. International Journal of Human Sciences, 13(1), 632-649. doi:10.14687/ijhs.v13i1.3506

Karasar, Ş. (2004).Eğitimde Yeni İletişim Teknolojileri Internet ve Sanal Yüksek, The Turkish Online Journal of EducationalTechnology - TOJET, 3(4). 16.

MEB. (2005).İlkögretim Sosyal Bilgiler Dersi 4-5. Simflar Ögrretim Program ve Kulavuðu (Ë̆itim Amacuyla Hazurlanan Taslak Baskıdir), Ankara.

MEB. (2005).İlkögretim Sosyal Bilgiler Dersi 6-7. Simflar Öğretim Program ve Kulavuæu (Taslak Basim),Ankara

MEB.(2006). İlkögrretim 6.Smrf Sosyal Bilgiler Dersi Öğretim Programı Kılavužn, Ankara.

Oğuzkan, F. (1993).Ĕ̈itim Terimleri Sözlüğ̈̈, Ankara: Emel Matbaacıllk.

Özdener,N.,\&Oztok, M.(2008). ICT sufficiency in cooperative projects via the Internet, WSEAS Transactions on ComputerResearch, 3(1), 51-60.

Rıza, E.T.(1997).Eğitim Teknolojisi Uygulamalar (1), İzmir: Anadolu Matbaası.

Saffron, M. E. (2008). An examination of theprocess of designing technology integrated secondary curriculum.Doktora Tezi, Wayne State University, Detroit, Michigan.

Schroll, D. (2007). Examining what influences a teachers' choive to adopt technology and constructivist principles in the classroom learning environment. Doktora Tezi, WaldenUniversity.

Sunal, Cynthia, Szymanski, Haas, Mary \& Elizabeth.(2005). Social Studies for the Elementary and Middle Grades. U.S.A.:Pearson Education İnc.

Şahin, M. (2000).Smrf ögretmenlerinin, ögretim sürecinde eğ̈tim teknolojileri ve uygulamalarna ilişsin etkinlikleri yerine getirirken karşılasstıklar problemler.Yüksek Lisans Tezi, Niğde Üniversitesi, Niğde.

Tarman, B. ve Baytak, A. (2011). Teknolojinin Eğitimdeki Yeni Rolü: Sosyal Bilgiler Öğretmen Adaylarının Bakış Açılanı, Gaz̧iantep Üniversitesi Sosyal Bilimler Dergisi 10(2):891-908

Tutgun, A.,\&Özdener, N. (2011). Bilgi ve İletişim Teknolojilerinin Eğitime Entegrasyonu: Bilgisayar Tabanlı Öykü Tamamlama Çalışması Örneği. Academic Journal of Information Technology (AJIT-e). 3(2), 1-24.

Yavuz, S. (2005).Developing a technology attitude scale for pre-service chemistry teachers.The Turkish Online Journal ofEducational Technology - TOJET, 4, 1, 17-25.

Yeşiltaş, E. ve Kaymakçı, S. (2014). Sosyal Bilgiler Öğretim Programının Teknoloji Boyutu, Uluslararası Avrasya Sosyal Bilimler Dergisi(Prof. Dr. Refik TURAN Özel Sayısı), Cilt: 5, Sayı: 16, s., 314-340

Yeşilyurt, E.(2007). Öğretim Araç-Gereçleri Kullanımına Etki Eden Faktörler.e-Journal of New World Sciences Academy, vol 2 (4), 300-312.

\section{Extended English Abstract}

As in other countries all around the world, one of the most important aims of Turkish National Education is to raise individuals who are equipped with the necessary knowledge of this time and age, who can adapt themselves to the physical environment and love their country and who are able to solve problems.

The developmental levels of countries can be evaluated by their achievement in science and technology. The most important factor in maintaining this development is education. Recently, the use of technology in education paved the way for different developments. By the development of education, creative thinking has come into existence from all parts of the society, and therefore people have started in to inquire, analyze, criticize, and produce. Education had such great impact in reflecting these knowledge and abilities to the human life that this impact cannot be deniable.

This study aimed to investigate The Attitudes and Opinions of Social Studies Teacher Candidates on the Usage of Technology in Education. In the quantitative section of the study, an attitude scale, 
Şimşek, Ü. \& Yıldırım, T. (2016). Sosyal bilgiler öğretmen adaylarının eğitimde teknoloji kullanımına ilişkin tutum ve görüssleri. International Journal of Human Sciences, 13(1), 632-649. doi:10.14687/ijhs.v13i1.3506

which was developed by Yavuz (2005), was utilised. In the qualitative section, experts' opinions were obtained, a four-item questionnaire was created and was tested on eleven teacher candidates (including some senior students) by utilising purposeful sampling and focus group discussion techniques. The data obtained from this study aimed to contribute to the related literature.

Main findings of the study were as follows:

- Of Social Studies Teacher Candidates attitude scores towards technology did not significantly differ from each other in terms of gender.

- Of Social Studies Teacher Candidates attitude scores towards technology did not significantly differ from each other in terms of their grade levels.

- Of Social Studies Teacher Candidates attitude scores towards technology did not significantly differ from each other in terms of the type of high school they graduated.

- Of Social Studies Teacher Candidates attitude scores towards technology significantly differed from each other in terms of the use of technology in the classroom by the staff members.

- Of Social Studies Teacher Candidates attitude scores towards technology significantly differed from each other in terms of the level of technological capabilities in the classrooms.

- Of Social Studies Teacher Candidates attitude scores towards technology significantly differed from each other in terms of the use of Internet in the course of teaching in the classrooms.

- Preservice teachers define technologyas a quality learning domain.

- Preservice teachers view technologyas a factor of improvement due to its increasing the quality of education and saving time.

- Preservice teachers report that when used for instruction, technology makes lesson subjects more accessible, permanent, useful and fun.

- Preservice teachers view technology as an element that opens the door to new methods of teaching.

- According to preservice teachers, instructional technologyis useful when used effectively. However, it does more harm than good when used in appropriately.

- Preservice teachers are generally positive about using technology for educational purposes because, applied hands-on, various technological tools not only increase the in structional quality but also have a positive impact on visual memory and learning retention.

- In addition to these positive effects, preservice teachers report some negative effects of using in structional technology. They report that the negative effects arise from equipment and infrastructural problems experienced both by instructors and educational organizations.

- Preservice teachers report usually using computers, projectors, and smart boards for their teaching practice. They also report that when they use these tools in their learning environments, they observe higher learning retention in learners'visual memory.

- Preservice teachers report that the key to make technology effective in education is turning the utilize dequipment into an integral part of the learning experience.

- Preservice teachers report that supporting lesson delivery with diverse instructional methods is another key point to make technology educationally effective.

- Preservice teachers also report that another way to ensure technology to be educationally effective is teaching by taking students' personal characteristics like age and developmental stage into account. 
Şimşek, Ü. \& Yıldıım, T. (2016). Sosyal bilgiler öğretmen adaylarının eğitimde teknoloji kullanımına ilişkin tutum ve görüssleri. International Journal of Human Sciences, 13(1), 632-649. doi:10.14687/ijhs.v13i1.3506

The findings obtained in this study showed that gender, grade level, and the type of high school graduated did not have significant impact on pre-service social studies teachers' attitudes towards technology. However, staff members' use of technology in their classrooms, the presence of technological devices in the classrooms, the use of Internet in the course of teaching had significant impact on their attitudes towards technology. These findings implied that educational institutes might have some shortcomings about infrastructure and might also point to staff members' inadequacy in terms of their academic backgrounds. Thus, these educational institutes are recommended to supply technological equipments that are necessary in the classroom and provide professional development programs to the staff members in order for them to increase the use of technology in their classrooms. 